\title{
Gabriel Naudé's library thought and early modern views into history and veins within political theory
}

\author{
Vesa Suominen \\ Oulun yliopisto \\ sohveli2012@gmail.com \\ https://orcid.org/0000-0001-8899-1133
}

The essay discusses Gabriel Naudés ideal of a censorship-free and publicly open library within Naudé's intellectual environment consisting of some early modern veins of political theory and views to history. An assumption is that the Naudéan ideal of library and some veins in early modern historiography and views to history could manifest somehow similar rationalities. The early modern vein of Tacitist historiography pursuing an unembellished manner realist and source-based description of the past could relate to Naudé's ideal of the censorship-free library and his technocratic and moral premises excluding political thought. Naudés ideal of the publicly open library, on the other hand, could relate to a different view to history that could be constitutive of morality too. The early phase of early modern Tacitism especially would be consistent with Naudé's thought of both the library and politics, while the other view to history could be, at best, only fragmentarily significant.

Keywords: Early modern age, historiography, library history, Naudé, Gabriel, philosophy of history, political theory

VERTAISARVIOITU

KOLLEGIALT GRANSKAD

PEER-REVIEWED
www.tsv.fi/tunnus

This article is licensed under the terms of the CC BY-NC-SA 4.o -license

Persistent identifier: https://doi.org/10.23978/inf.107577 


\section{Introduction}

Robert Damien (1949-2017) was a French professor of philosophy with a particular interest in library philosophy. Damien was especially interested in Gabriel Naudé (1600-1653), a French erudite libertine and librarian in service of several potentates. Naudé's career culminated in the 1640 s as the librarian of Cardinal Jules Mazarin, who followed the famous Cardinal Armand du Plessis de Richelieu as the king's first minister. In this essay, I shall take as my starting point the picture of Naudé that Damien creates in his monograph Bibliothèque et État: naissance d'une raison politique dans la France du XVIIe siècle (Damien 1995).

Naudé $(1627,113)$ in his Advis pour dresser vne bibliothèqve suggested that the library should be publicly open. Furthermore, the choice of books in the library should be in the seventeenth century remarkably tolerant and free of censorship (op. cit. $37 \mathrm{ff}$.). Many within the library, information, and documentation (LID) field and studies have considered those suggestions exceptionally modern, liberal, and even democratic (see, Shera 1976, 128, Sievänen-Allen 1978, 82-83, and Quodtrup 2007, for instance ${ }^{1}$ ). Related to Naudé's ideal of a censorship-free library and a kind of equality of books, Damien $(1995,308)$ boldly argues that "egalitarian democracy of bibliography precedes the political democracy".

Several authors have also characterised Naudé's thought as historical, humanistic, and philological (see, for instance, Lemke 1991; Armenteros 2011, 99 ff.). Damien $(1995,209)$ writes about the history-dependence of knowledge with Naudé: "Knowledge is not without a past. [...] None really begins [to know], but continues laboriously."

On the other hand, Naudé lived in a tumultuous time. Relatively recent, utterly devastating Huguenot Wars (1562-1598) made, as we shall see, the idea of centralised solid power plausible (see Hoffman 1994, 248). According to Damien, "Naudé's central experience" was

..., we know it, a sharp feeling of the possible destruction of everything. Nothing can escape this, and Naudé has experienced and noted it as regards religion as well as science, as regards politics as well as nature. (Damien 1995, 235.)

Shera's and Sievänen-Allen's books as introductions to the field of study - the latter as the first one written in Finnish - are typical presentations and constituents of conventional wisdom within the field of study and practice. With Quodtrup as well, the remarks on Naudé containing specific mention of democracy appear as a rhetorically motivated introduction to discussing a more specific present-day issue. 
In this essay, I shall denote this assumption by Damien briefly as Naudé's desperation.

"Evading the ontotheological illusions (Echapant à illusions ontothéologique)" (Damien 1995, 61) or "the absence of transcedent foundation (l'ábsence de fondament transcendant)" (op. cit. 241) would make immanent and contingent history the only foundation for Naudé. Still consistent with Naudé's desperation, the state would become the only shield for humans' social life within the destructive history with no permanence. Politics with Naudé thus becomes, if expressed by a word representing later modernity, a purely socio-technological or 'engineerish' enterprise to maintain the state. (See op. cit. $235 \mathrm{ff}$.) My fundamental assumption is that there is a resemblance or a kind of homology of logic behind the Naudéan library and some early modern views of history. The foundation of this assumption will become visible below.

The question thematising this essay, then, would be as follows. What could or should the history and the Naudéan library give or 'teach' the readers and society. The question would be whether morality could have anything to do with Naudé's understanding of politics. Would or should the history and the Naudéan library give the readers and even the society around the library (i) advice for protecting, maintaining, and fortifying the state only or (ii) rationality in the broader sense, including some moral obligations and restrictions too as parts of political thought, in addition to purely technical advice? The latter option (ii) could mean for those in power morality-based restrictions and obligations related to the ideals such as justice and the interests and possibly existing rights of those affected by implemented policies. For brevity, I shall in this essay denote such morality-based elements by the single word morality.

Structurally, the essay consists of two major parts, Reasonings (1) and (2). Both of the Reasonings will have as their core a particular early modern view into history. Reasoning (1) proceeds from a particular early modern vein of unembellishedly realist historiography and a vein in early modern political thought neither of which left much space for moral restrictions for the one in power. Given the assumed significance of history with Naudé, Reasoning (2) proceeds in a highly speculative manner, I should admit, from still some different views into history, present in the early modern centuries. Could history itself, after all, be the foundation of even richer rationality among humans, perhaps including even something like the ideals of justice, equality, etc., which could bring some elements of morality into politics too, all the time without any ontotheological foundation? 
Thematically, my reasoning will consist of reconstructing some features of Naudé's own thought and possibly relevant veins in the early modern intellectual history around Naudé. As sources for my reconstruction of Naudé's thinking, I shall use Naudé's texts complemented by commentaries. Damien (1995) has a particular position among the latter. Appealing to commentaries is necessary already because Naudé himself does not write very much about the philosophical foundations of his thought. For reconstructing the general veins of intellectual history around Naudé, I shall use appropriate later studies and literature on the early modern history of ideas. Original early modern texts will complement and, to a degree, contest or support the picture based on later studies.

\section{Reasoning (1), from veins in early modern political theory and historiography to Naudé's ideal of an uncensored library}

I already referred to Naudé's reputation as a precursor of modern, liberal, and even democratic ideals of the library. However, in the eyes of posteriority, Naudé's political views were hardly very modern, let alone egalitarian or democratic. A striking example is his praise of the Massacre of St. Bartholomew Day (1572) as "a very just and remarkable action the cause of which was more than legitimate (une action très-juste, \& tres-remarquable, \& dont la cause estoit plus que légitimé)" (Naudé 1639/1667, 169). Naudé clearly understood that his view was scandalous even in his own time. ${ }^{2}$

Damien (1995) combines Naudé's political thought with Jean Bodin (15301596), a French jurist and theorist of politics. Bodin's (1576) classical work Six livres de la repvblique was published four years after the St. Bartholomew Day massacre. Especially Bodin's notion of sovereignty appears as a possible justification for Naudé's political views. Against a broader map of early modern political thought, on the other hand, we shall see how extreme Naudés political views were even in his own time. Consistent with them could be a vein in early modern histography denoted as Tacitism. This view of historiography seems to have something in common with Naudé's in his time exceptionally tolerant and censorship-free views of what kind of books there should be in the library.

2 Six to twenty thousand would be a "modern estimate" of the number of protestants killed during the weeks in Paris and months in the provinces that the massacre was going on (Johnson \& Koyama, 2012, 26). 


\section{Jean Bodin's political theory and Naudé's 'engineerish' conception of politics}

According to Bodin, the state or "la republique" (republic or commonwealth or, in the English translation from 1606, for instance, commonweale), is

... a lawfull gouernment of many families, and of that which vnto them in common belongeth, with a puissant soueraigntie (vn droit qouuernement de plusieurs menages, \& de ce qui leur est cõmun, auec puissâce souueraine) (Bodin 1576, 2; transl. from Bodin 1576/1606, 1.)

In early modern France and even in Bodin's mind, probably, the sovereign would most plausibly be the king. ${ }^{3}$ Then again, the notion of the republic with Bodin is quite general and reflects Aristotle's (-322BC/1959, 281-283) classical classification of the forms of government, though omitting the corrupted forms. According to Bodin, "there are but three estates or sorts of Commonweales", which are "Monarchie", "Aristocratie", and "Democratie or a popular estate". (Bodin 1576, 219; transl. from Bodin 1576/1606, 184.) The fundamental claim with Bodin would be that sovereign and sovereignty are essential elements in the republic or state ("le fondemet principale de toute Republique", Bodin 1576,152$)$. It would be only secondary that the king is the sovereign.

There has been an already classical consensus of Bodin's significant position within the history of the notion of sovereignty in political theory (see, for instance, Merriam 1900, 134). Bodin reasoned that nothing could restrict the sovereign since otherwise, no sovereignty would exist, as if by definition. Among other things, Bodin (1576, 133 ff.) ponders whether conventions made and promises and laws given by the sovereign or some earlier king could restrict the sovereign. Though depending on more specified conditions, the answer in many cases is that they cannot.

Naudé, in his Bibliographia politica, praises Bodin as a theorist like whom there was no one in hundred (Naudé 1633/1641, 40). ${ }^{5}$ Importantly for Naudé, according to Damien $(1995,218)$, politics became in Bodin's thought a valid field of scholarship on its own. No more was it merely an applied field of carrying out what theology or otherwise founded morals demanded.

3 Applying the so-called Salic Law excluded the option of a sovereign queen in the French kingdom.

$4 \quad$ Merriam writes: "The first systematic discussion of the nature of sovereignty was made in France by Jean Bodin."

$5 \quad$ Freely translated, the original and more metaphorical Latin "nullus tamen iaculum extra metam expediuit excepto Ioanne Bodino" (Naudé 1633, 32) tells that none but Bodin threw the javelin far enough. 
According to Naudé $(1633,42$ and 1633/1641,54), there are three tasks on which everything else in politics ("administration politique des Royaumes \& des Estats") would depend. Summarised by Damien (1995, 223), they would be (i) establishing, (ii) maintaining, and (iii) and developing the state. In Naudé's own more wordy formulation, the last of these is related to situations where the state is about to collapse. Rather than a practice of carrying out some moral ideals, God's will, or otherwise based morality or ideals of justice, politics thus conceived of would be very much a socio-technological matter, an 'engineerish' activity of maintaining and protecting the state at any cost. For Naudé, good politics required even fine-mechanical skills. Minute moves or events can save or destroy whole empires (see Naudé 1639, 224-225).

Considering what one was supposed to write or say publicly, a kind of depreciation of religion was particularly controversial. Damien writes as follows about Naudé's view of Church:

It [the Church] thus constitutes itself as an institutional apparatus of domination of opinions, which are necessary for conserving the established political order (Damien 1995, 133).

(See also, for instance, Naudé $1639 / 1667,247$.$) We probably should notice$ here that with Bodin, there are frequently appeals to moral and religious foundations to be respected.

According to Preston King (1974, $291 \mathrm{ff}$.), there is a tension between justice and maintaining order throughout Bodin's thought. The sovereign should also respect some rights of the subjects and particularly their proprietary rights. Illustrative enough is Bodin's quotation from Seneca: "Vnto kings belonged the power of all things, and vnto particular men the proprierie (Ad reges potestas omnium pertinet, ad singulos proprietas)." (Bodin 1576, 151; transl. from Bodin 1576/1606, 110.) Furthermore, the sovereign should not act contrary to the "law of nature and God (la loi de nature et de Dieu)" (op. cit. 130, for instance; transl. from Bodin 1576/1606, 154). According to Bodin, on the other hand, "The sovereign, like the subject, is bound by the law of God and of nature, but his obligation in this respect is to God, by whom it will be enforced" (Dunning 1896, 94). In this sense, the king's obedience to the law of nature and God would become a matter of conscience purely and remain between the sovereign and God only. This way, Bodin could have wished to exclude all authority appealing to religious arguments and exercised over the sovereign by any human agents, such as the Church or pope. Simultaneously, he could have avoided accusations of ungodliness - though we perhaps should not assume that his motives were only tactical. In any case, King $(1974,295)$ quotes quite 
approvingly J.U. Lewis's claim that "social and political order rather than justice is given a priority all through the Six Books" by Bodin. The protection for the subject could remain with Bodin "a flimsy and highly theoretical notion of natural law, which the king was supposed to observe (Hoffman 1994, 249). ${ }^{6}$

The aspects of Bodin's thought discussed here, in any case, could suggest that exclusion of morality from politics was much more radical with Naudé than with Bodin. Naudé $(1625,73)$ also saw mechanics as the ideal among all the sciences, which perhaps shows that purely technical patterns could have dominated his thinking throughout. In some instances, he looks at the whole of the universe - including, among other things, social phenomena such as the towns, religions, and kingdoms - as a "great Machine (grande Machine)" and thus also as subjects to change and corruption (Naudé 1653/1739, 143-144). Affected by corruption, the state too can break and needs repairing. For Naudé, on the other hand, such repairing would have been a purely technical task, very much like repairing any engine. Justice and other moral ideals would probably matter only as far as they - or an illusion of them - could make the state stronger.

\section{Naudé's extraordinary radicality within a wider map of the early modern political thought}

Before going ahead, I still should emphasise that the issue here is not how people - particularly those in power - actually were thinking and acting. Following kinds of questions arise, instead. How political and moral issues tended to be discussed? What was appropriate to express publicly? What the authors, nevertheless, considered necessary to write because of the subject matters dealt with in their texts?

One could see a bend - though not a total break - in appealing to moral arguments during the first modern centuries. Many traditions of political morality were well alive. ${ }^{7}$ The notion that typically denoted the intellectual

$6 \quad$ Furthermore, in many of the cases of appealing to the law of God, Bodin actually is reminding the judges of their obligation to punish severely enough since it is the demand of the law of God (Bodin 1576, 364, for instance). Then again, the law of God as an argument against slavery, for instance, has a different role related to the rights of people (Bodin 1576, 45).

We perhaps could see a sharper and even somehow dramatic break, related to the secularisation of thought, in the early modern centuries. Religiously based morality could have quite simple and forcing inner logic: if God is good - or, even the determinant of goodness - what God wills would undoubtedly be good, as if by definition, and it would be righteous to heed this supreme guidance. Once this logic becomes even a little less convincing - as in some respects, at least, was the case in the early modern centuries - the situation becomes much more complicated. 
foundation, reason, wisdom, etc., needed and to be applied by those using the power within politics was prudence or prudentia (transl. to Latin from the Greek phronesis; I shall use below the Latin word). Jacob Soll's (2014) account of the developments of the notion is illustrative as a starting point for contextualising Naudé's thoughts. With Socrates, Plato, Aristotle, and Cicero in Greece and Roman Antiquity, the notion of phronesis, or prudentia, evolved with emphasis oscillating between morality and the practical capacity of effective action. The same oscillation continued in the Middle Age, though influenced now by Christianity. For Church Father Augustine (354-430), prudentia was dominantly spiritual, whereas later, with Thomas Aquinas (1225-1274), also the other moments of the ancient notion gained attention once again.

Synthesising Aristotle, Cicero, and Augustine, Aquinas created a practical yet necessarily moral theory of prudence, thus mixing Aristotelian political philosophy with Christian views of the state. (Soll 2014, 36.)

Closer to Naudé's time, the situation becomes complex. Many of Niccoló Machiavelli's (1469-1527) contemporaries, according to Soll, had still "appropriated Aristotelian and Ciceronian theories of prudence in the context of Christian humanism". With Machiavelli, in turn, prudentia (prudenza) was "a tool for dissimulating vice and retaining political power" and purely secular cleverness for effective political actions (Op. cit., 37). More than Machiavelli himself here matters the meaning of the notorious Machiavellism in Naudé's intellectual environment. After the Massacre of Saint Bartholomew Day, "many Protestants and Catholic moderates believed that the fanatical attack had been inspired by a Machiavellian form of political cynicism and cruelty" (op. cit, 31, see also Beam 1982, 35-41). In a kind of renaissance of the Machiavellian thought, the Flamish philologist and political theorist Justus Lipsius (or Lipse, 1547-1606) - with modifications perhaps aiming at better 'salon eligibility' became influential (Soll 2014, 32).

Christian traditions and the effectiveness of government, on the other hand, did not exclude each other necessarily. Ferenc Hörcher (2019) outlines the tensions in early modern political thought in terms of (i) the political realism of Machiavellian views "feared to include a break away from traditional Christian values" (op. cit., 162), (ii) the "classical and Christian teachings of the role of virtue in politics" (op. cit. 167), and Hörcher's article's actual topic, i.e. (iii) the efforts to combine (i) and (ii), Lipsius and Michel de Montaigne as examples (see also Hörcher 2016). The foundations of the state should be the "reign of God (Régne de Dieu)" writes even Cardinal Richelieu $(-1642 / 1689,244)$, the mighty and at least by his reputation ruthless first 
minister of King Louis XIII. Appealing to natural law was frequent (see, for instance, Hörcher 2016, 200). We already saw above how even Bodin demanded that the sovereign should respect the law of nature and God and the subjects' proprietary rights, for instance.

Even ideals like freedom and equality had been present in early modern political thought. By the notion of "exclusivist republicanism", James Hankins $(2016,73)$ means political ideal that would exclude the hereditary power and makes the will of the people the only legitimate foundation. Hankins also writes that for Leonardo Bruni (circa 1370-1444), the chancellor of the early phase of the republic of Florence, "Political equality makes for freedom, and freedom for justice" (op. cit. 86). Such radical egalitarianism certainly was marginal in early modern France. The circles within or close to which Naudé lived - and Naudé himself, especially - hardly saw much realism in it. ${ }^{8}$

The later developments in Florence, on the other hand, manifest one particular early modern trend - a political megatrend, actually - that also Naudé probably engaged quite full-heartedly. Alessandro de' Medici - an illegitimate descendant of the earlier, at least in their public conduct quite exclusively republican Medicis - became in 1532 the duke of the Florentine Republic. Power thus becomes hereditary in the former - and, we should remind, in itself rather oligarchic - Florentine Republic and the Grand Duchy of Tuscany formed soon afterwards. (See, for instance, Boutier \& Sintomer 2014, 1084.) During the first modern centuries, a general trend was that trust in the merits of mighty central power and absolute monarchy advanced. Royal absolutism overcame the feudal order with its relatively firm and well-defined rights of nobility. Similar was the fate of more or less exclusively republican ideals based - to a degree, at least - on the rights of the citizens. We shall see this mainstream below once again within the Vician philosophy of history.

Viewed against this background, Naudé's political thought and what he wrote seems to represent the bend in appealing to moral arguments about and around early modern politics in an exceptionally radical manner. Particularly illustrative could be to return to the notion of prudentia with a comparison between Naudé and Lipsius (1589/1632, 178 ff.). Lipsius had a kind of 'pure' prudentia, on the one hand, and what he denoted as prudentia

$8 \quad$ We perhaps should notice Étienne de La Boétie (1530-1563) and his text Le discours de la servitude volontaire ou le contr'un (La Boétie 1549/1576/2009). The very beginning of the passionate and relatively short text is quite illustrative. "Homer tells that one day, speaking in public, Odysseus said to the Greeks: It is not good to have many masters; let us have only one of them." One should have concluded, according to La Boétie, that "domination of many masters cannot be good since the power of one, once he takes the title of master, is hard and disgusting." (Op. cit 11.) 
mixta, on the other. Naudé $(1639 / 1667,53)$ as well divided the forms of prudentia into (i) "ordinary and easy, proceeding along the usual paths and without exceeding the laws and customs of the country" and (ii) "extraordinary, more rigorous, severe and difficult". Like Lipsius' prudentia mixta, the latter would be the logic to be followed in extraordinary situations seriously threatening the state. It would allow otherwise forbidden and illegal courses of action. Lipsius (1589/1632, 182-183), furthermore, classifies such actions or frauds into light (levis), medium (media), and grave (gravis) ones. Lipsius recommends the frauds classified light and tolerates those classified to the medium level but sharply excludes the grave ones: "istam damno" (op. cit. 183). As we saw, Naudé was ready to defend actions like murdering thousands of people. Such murdering probably went well beyond the light and medium frauds accepted or even recommended by Lipsius - the man characterised by Soll as a Machiavellian. Naudé, furthermore, actually marginalises and even banalises ordinary prudentia, which would have no use in politics, which Naudé actually identified with coup d'etat, according to Damien (1995, 229 and 252).

According to Jean-Pierre Cavaillé, what drove Naudé was the "concern of showing that he goes further (soin à montrer qu'il va plus loin)" than others. Cavaillé's remark could also tell something about Naudé's person, character, and mentality. Naudé's positive words of men like Emperor Tiberius or King Louis XI of France was illustrative in this sense (Naudé 1639/1667, 55). One closer to the mainstream of political thought considered mentioning, let alone praising, those men a sign of notorious Machiavellism (Bakos 1991, 400-401).

While dealing with Naudé's position on politics and morality, Cavaillé further refers to Aristotle's notions of phronesis and techne. He concludes that Naudés position seems "unreducible to the Aristotelian eminently moral definition of phronesis that orients all the actions towards the good (irréductible à la définition aristotélicienne de la phronèsis, éminemment morale, qui oriente toutes les actions vers le bien)". According to Cavaillé, however, neither would Naudé's view reduce to purely technical intelligence. Following Cavaillé's thought, as we perhaps could summarise it, the prudentia of coup d'etats would be a virtue. It would be virtuous to make oneself free from all the moral hesitations inherited from the past but useless in the present situation. (Cavaillé 2006.) 


\section{The early phase of the early modern Tacitist historiography and Naudé's uncensored library}

The developments of the notion of prudentia could provide us with a promising candidate for expressing what actually is the understanding required in politics. Because of the Naudéan desperation excluding all ontotheological foundations, history is very significant as the source of prudentia. We could now ask what kind of history and view into the past could be a foundation of the kind of prudentia that the Naudéan library plausibly should advance.

I would here pay attention to a vein denoted as Tacitism in early modern historiography. Depicted by Soll (2003), Tacitism in this sense meant an "empirical" approach based on sources and opposed to the other kind of history-writing, denoted as Ciceronian and characterised by emphasising eloquence in telling about the past. Soll writes:

In his masterwork of historical method, the Methodus ad facilem historiarum cognitionem (1566) Bodin describes the connection between pragmatic politics and accurate history. Going against the Ciceronian school of historical rhetoric, he insists that eloquence constitutes an obstacle to the truth. (Op. cit., 300.)

Soll also mentions the manuscript Reqveil des roys de France, collected for the young king, Charles IX, by the royal archivist Jean du Tillet. The book is by its nature a kind of basic education and handbook for the ruler, containing plenty of details of the history of the French Kingdom, the kings and queens, their heirs, nobility, administrational bodies, etc. (Du Tillet 1545/1566; see also Du Tillet 15??/1580.)

On the other hand, the accurate and unembellished writing about the suspicious, sometimes cunning, and now and then even outrageous methods of using power gave the critics good starting points, particularly after the books were published in smaller formats and cheaper editions. Tacitist historiography thus evolved into criticism of prevailing political conditions and practices.

Quite a noteworthy example mentioned by Soll (2003, 306-307) of Tacitism is Istoria del Concilio Tridentino by Paolo Sarpi (1552-1623), a Venetian statesman. The book was initially published in 1619 in London by pseudonym Pietro Soave Polano. Sarpi was criticising or even denigrating the Council of Trent (1545-1563) that was most important for the Catholic Reformation. (Sarpi 1619/1974.) The book was a part of the struggle between two state-like sides, the Serenissima repubblica di Venezia and Papacy or 
the Holy Siege, and, in this sense, belonged to foreign politics. Defending the secular power in a single state - were it Venice or France - against the papal authority should have pleased Naudé. On the other hand, we also could see Sarpi's book criticising the practices of power within the Catholic world as a whole. In this sense, it would come closer to the later critical Tacitism's typical thematic of criticising the political order and power within some particular state and society. Naude perhaps did not appreciate such criticism by the subjects or those otherwise inferior in the established order. In any case, Naudé's comments in his Bibliographia politica on Sarpi's book were not very favourable (see Naudé 1633, 108). ${ }^{9}$

Soll still mentions as representatives of the later critical Tacitism authors like Pierre Bayle (1647-1706), the classic of the freedom of conscience, and Montesquieu (1689-1755). Still another example of this phase in Tacitist historiography could be Essai sur le despotisme by Count Honore-Gabriel de Mirabeau (1775), a nobleman who later became one of the leading figures of the early years of the Great Revolution (see, e.g. Hardman 1999, 26-27). Not many of the French kings mentioned by Mirabeau did avoid the blame of despotism - though there were some exceptions, such as Henri IV (Mirabeau 1775, 95 and 100, for instance).

Soll $(2003,306)$ writes that "by the beginning of the seventeenth century the critical Tacitean tradition evolved out of the control of crown," and less than hundred years later, "the crown perceived critical history as a serious menace to absolutism." Soll ends his account of the critical Tacitist historians as follows:

Their use of historical induction and their handling of evidence were rhetorical products of the Tacitean tradition. Yet their Tacitism was 'red'. It would be viewed as a revolutionary invitation by the immediate

Notwithstanding all said, it still is a little surprising that Naudé $(1633,108)$ seems not to appreciate Sarpi's (or Soave's) book. Naudé and Sarpi had much in common. Sarpi appreciated Gallicanism and the French party of politiques that wished to exclude religious controversies from politics (Wootton 1983, 34 ff.). Neither of these ideas was far from Naudé's thought either. On the other hand, there was some discussion about whether all told by Sarpi in Istoria del Concilio Tridentino had a solid foundation in sources (op. cit., 104). A problem explicitly mentioned by Naudé is that storia del Concilio Tridentino - like several other books and authors, Machiavelli included unveils so-called secrets of state or arcana imperii that should remain secret (Naudé 1633, 108; see also Catteeuw 2010). What comes to Machiavelli, interestingly enough, his name has disappeared from the list of those criticised along with Sarpi's book in the French translation La bibliographie politique dv Sr Navde from 1641 (see Naudé 1633/1641, 156). 
inheritors of 1789. Critical history had evolved into a tool to dismantle the very crown that Bodin had tried so hard to protect. (Soll 2003, 316).

Neither could we assume that the doubts about the justification of power present in the Early-Englightenment - let alone the ideals of the French Great Revolution - would have been very consistent with Naudé's thought. ${ }^{10}$

On the other hand, we could plausibly consider similar ideas behind the early phase of the early modern current of Tacitist historiography and the Naudéan censorship-free library. Soll (2003, $304 \mathrm{ff}$.) refers to this early phase as "royal Tacitism" and combines it with the names such as Bodin, du Tillet, and Lipsius. Unlike critical Tacitism, where the accurate history presentations revealed quite suspicious ways of exercising power, royal Tacitism gave good examples from which the one in power could learn governing skills. Naudé's Considerations, of course, provides us with plenty of examples of such teachings for particularly extraordinary situations - though Naudé himself planned to have printed only twelve copies and thus reserve the book for quite a restricted audience (see Naudé 1639, Au lecteur).

According to Damien (1995, 263 ff.), Naudé's ideal for the king's or ministers' counsellor would be "the man without qualities (l'homme sans qualité)", the librarian who had no ambitions of his own that could corrupt his advice. While counselling the king or minister, furthermore, the librarian could draw from all the knowledge in his library - and, we could add there now, from history viewed in the Tacitist manner. Concretely, such Tacitism could consist of ways of writing as well as assumed ways of and motivations in reading about the past. The royal-Tacitist historian could be un historien sans qualité, thus anticipating some dominant ideals of later historiography and the positivist ideals of science there.

Given the above assumption of Naudés conception of politics as a socio-technological or 'engineerish' activity, we probably should think that both the Naudéan library and history would be kind of 'model books'. Both history and the Naudean library would cumulate experience of the better or worse results of some particular courses of action in some particular kinds of situations. To base one's political moves realistically on facts, one should have an open mind to all that someone has said about the reality and facts.

10 Reminiscent of Tacitism as a part of the Enlightenment, Soll (2014, 51-53) goes ahead with the notion of prudentia and Machiavellism. We could somewhat simplistically say that in the transformations in the notion of prudentia, one first addressed the prince and then the state, suggesting for both of them some self-preservation. Finally, however, one would recommend self-preservation to individual citizens, thus approaching the ideas of individual citizens' rights. 
However, moralising about the facts and reality - as critical Tacitism tended to do - could be in many respects even harmful in solving the faced problems.

\section{Reasoning (2), from an alternative view to history towards Naudé's publicly open library}

Reasoning (1) above created a picture of Naudé's political thought where there was no much space for any moral obligations or restrictions for those in power. In Reasoning (2), I shall outline an option to relate Naudés library thought to a fundamentally different way to look at history, which also was present in the early modern centuries.

Carolina Armenteros - in her monograph titled The French idea of history and mainly treating of a French conservative politician, Joseph-Marie de Maistre (1753-1821) - emphasises as follows the significance of history in Naudé's thought already.

Naudé argued that the mind and spirit are best developed by common sense, which is in turn nurtured [...] by readings in the human sciences and especially in history and literature. [...] From a similarly erudite and anti-Cartesian point of view, Giambattista Vico (1668-1744) recommended [...] that young minds be formed by reading the great writers of antiquity. (Armentros 2011, 99-100.)

We certainly can proceed here with a most reserved mind only. "To be sure, no straight line can be drawn from Naudé to Vico to [...] to de Maistre" (Armentros 2011, 101). Some formulations by Damien could be encouraging us in this otherwise highly speculative exercise, however. ${ }^{11}$

11 We could also see in this tradition some origins for ideas, which have appeared within various human, social, and cultural fields of scholarship since the late twentieth century, including LID-studies (see, for instance, Capurro 1992, Talja, Tuominen \& Savolainen 2005, $89 \mathrm{ff}$., and Suominen 2016). As the linkage, we could see the idea of the utterly social foundation and nature of knowledge and understanding with more or less emphasised moments of traditions and historicality. 


\section{Alternative views into history and the possible historical constitu- tion of morality}

The Neapolitan historian Giambattista Vico - characterised even as the "Italian Hegel" (see, for instance, Ježić 2015, 273) - lived and created his philosophy of history less than a century after Naudé. A fundamental part of Vico's thought is the so-called verum-factum principle. We perhaps could express the idea shortly as follows. Humans can know about and have access to the rationality of the "world of nations or civil world" made by humans since "the true and the made are convertible (verum et factum convertuntur)" (Vico 1710/1835, 56). Vico writes:

Whoever reflects on this cannot but marvel that the philosophers should have bent all their energies to the study of the world of nature, which, since God made it, He alone knows; and that they should have neglected the study of the world of nations or civil world, which, since men had made it, men could hope to know. (Vico 1744/2015, 87; transl. from Vico 1744/1948, 86.)

Through making their history and society, a kind of common rationality would exist between the humans who have created societies and history, on the one hand, and the humans investigating them, on the other. The case with nature made by God is different, and for this reason, humans' ability to develop science and knowledge of nature is problematic and limited.

On the other hand, Vico's way to combine society and history did not become mainstream of the eighteenth-century Enlightenment. However, we can find in Vico's thought a way to see in a secular manner the origin and background of some ideals that later became the political Enlightenment's cornerstones. In any case, we could consider Vico's thought as an early instance of ideas of what I would denote as constitutive history, which I shall open a little later. Finally, our excursion to Vico might help us see Naudé's relatively straightforward and reduced political thought within the frame of a transition time between the Middle Age and earlier Renaissance, on the one hand, and the advancing modernity and Enlightenment, on the other (cf, Suominen 2019).

Related to my argumentation above, it is noteworthy that what history can constitute also contains virtues and, in this sense, morality (see, for instance, Miner 1998, 54 ff.). Vico's (1744/2015, 29, for instance) philosophy of history contains a periodicalisation of history, the (because of inescapable corruption recurring) sequence of the ages of Gods, heroes, and humans (l'éta degli Dei / 
eroi / uomini). Each of them, then, would have the virtues and premises of morality of their own. The following passage could illustrate in this respect Vico's reasoning about l'éta degli uomini:

The people had finally come to understand that the rational nature (which is the true human nature) is equal in all men. From this natural equality [...] they gradually brought the heroes to civil equality in popular commonwealths. [...] But finally, as the free peoples could not by means of laws maintain themselves in civil equality because of the factions of the powerful, but were being driven to ruin by civil wars, it came about naturally that, obeying a natural royal law or rather natural custom of human peoples, they sought protection under monarchies, which constitute the other type of human government. (Vico 1744/2015, 28; transl. form Vico 1744/1948, 16.)

We perhaps should notice before going ahead that Vico and Naudé would probably not have disagreed very much on the rationality of seeking "protection under monarchies." They both lived during the same historical period characterised by a political mega-trend toward absolute monarchy, which manifested also in the above mentioned later developments in the Republic of Florence. Even Naudé could appreciate that all but the almighty king himself are equally the subjects to the king within the absolute monarchy. Had Naudé not witnessed, even during his lifetime frequently, how the highest nobility, including the king's closest relatives - so-called princes of blood - revolted against the growing royal power and thus endangered the state (see, for instance, Abad 2003). Compared to Vico, on the other hand, Naudé's thought could be rather crude.

A most noteworthy notion in the quotation from Vico above is "natural equality", which is characteristic of the "age of humans" and the premise belonging most markedly to the sphere of politics and morality. It would be a moral premise that concerns justice as an ideal of the state's and power's fundamental structures. It could also imply plenty of further obligations and restrictions for the one in power.

With Vico, both equality and freedom belong to quite a primitive condition of humans already. A kind of self-sufficiency of separate families would have been the foundation of "natural equality" in the "extreme simplicity and crudeness of a life", in primitive social life with no higher significant levels of power. "Each of the fathers was sovereign in his own family." (Vico 1744/2015, 161; transl. from Vico 1744/1948, 162.) Vico also claims that "The contests waged by the orders in the cities for equality of rights are the most powerful means 
of making the commonwealths great" (Vico 1744/2015, 78; transl. from Vico 1744/1948, 75). Equality and justice (giustizia) in the Italian text combined with it already appear as principles in arranging the power in the state-like social and political wholes to advance their vitality. In both of these examples, the origin of the ideal would be a kind of functionality or communities' attempt to adjust to the particular historically evolved conditions of their life.

We actually could see some logic of adjusting even in Vico's account of people who "sought protection under monarchies". If equality as such and all-comprehensively is not possible, the second-best option could be that all but the sovereign king are equally the subjects to the king. Still another, quite simple, but also illustrative example of such adjusting and functionality is Vico's view that the virtue of patience emerges within the institution of marriage. Above, we also saw how the foundation of equality could be the similarity of the true rational nature of humans and, probably, an idea that those who are substantially similar should also be socially equal. If compared with the aspects of social functionality and adjusting, such foundation would become closer to the idea of a genuinely and purely moral maxim. We perhaps should assume that various possible foundations are present in Vico's thought.

Some similarity with what I mean by constitutive history has the fundamental Catholic idea of Traditio Apostolica proceeding from the eyewitnesses of Christ's life as an oral and written heritage, the various versions of the holy texts as moments of this tradition (cf., for instance, Tavard 1962). There would also be a clear awareness of the problems in taking some text as the original foundation (see, for instance, Mali 1989, 157 ff.; Simon 1690). Traditio Apostolica was a currently discussed and even controversial issue in Naudé's own time, too, because of the Protestant claim that the scripture or the Bible alone (sola scriptura) would be the authority in matters of faith and Christianity. On the Catholic side, on the other hand, the Council of Trent had reinforced the doctrine of Traditio Apostolica (see, for instance, Mali 1989).

Within what also evolved within Traditio Apostolica, the issues relevant to the genuinely political sphere too were present (see Szuromi 2015, $198 \mathrm{ff}$.):

St. Thomas made clear that morality is that column of the legal system that is rooted in the Bible, in the apostolic Tradition and in the teaching of the magisterium of the church. (Op. cit., 200)

Justice, furthermore, could have implied even some form of equality with Aquinas (see Gilson 1948, 424-425). For Naudé, on the other hand, such politico-moral implications probably were only unnecessary restrictions harmfully damaging the effective exercise of power for protecting the state. 
The foundation of and ultimate authority behind the ideals of justice that Traditio Apostolica may produce or reveal, would certainly be divine. Then again, we could conceive of the processes leading to them - producing or perhaps revealing them - as discoures and common use of reason taking place among and between the humans.

Vico, in turn, argues for what he writes about various institutions in an anthropological and, in this sense, secular manner, appealing only to what he can find in purely secular history. According to Vico (1744/2015, 87; transl. from Vico 1744/1948, 86), all the nations "have some religion; all contract solemn marriages; they all bury their dead". Further, religion, marriage, and funeral "are the divine things among the gentiles, from which came later all their human things" (Vico 1744/2015, 18; transl, from Vico 1744/1948, 7) ${ }^{12}$. After those three institutions, however, humans would have made their history and, in this sense, a secular foundation for virtues as well as morality. ${ }^{13}$

\section{Constitutive history and evolvement of common rationatlity?}

What I would denote as constitutive history consists of our participation in, looking at, and recognising history as constitutive of our knowledge and our rationality in quite a broad sense. Crucial is the option of rationalities common to contemporaries as well as to people in the past. With Vico, this option has its foundation in the verum-factum motive. Over two hundred years later Hans-Georg Gadamer (op. cit. 264) suggests that we should not understand a text "as a mere expression of life", but take it "seriously in its claim to truth".

Moments in evolvement and even visible signs of common rationalities could be some kind of consensuses. Then again, sometimes one can quite legitimately challenge the most widely prevailing views. Consequently, consensus would not necessarily be the ultimate foundation of the validity and authority of what it concerns. Above, we already saw how God's will could be the ultimate authority behind what Traditio Apostolica can procude or find. With Vico, there were foundations such as social functionality and even the similarity of

\footnotetext{
12 Vico depicts this in a purposefully mythological manner by which he - though personally a devoted Catholic - extends his argumentation to concern for all the people, instead of the Christians only.

13 We perhaps should still notice that both with Vico and Traditio Apostolica, the divine providence has a role in those processes of history and traditions of human thought. However, in my view, this would not necessarily annihilate their secular nature. Divine providence could be something that humans can just hope and pray for to support their otherwise purely human pursuits.
} 
essential nature. Here we should accept that there can be many kinds of ultimate authority inherent in what the human processes can produce of find.

Furthermore, we should not assume that consensus should - or could emerge and exist between all the people. Particularly in unequal societies, not all the people - perhaps not even any quantitatively significant portion of them - could or should have any say on the content of consensus. For a significant consensus, it might be enough that some consensus prevails among a sufficient amount of people who are significant enough because of their social position in some particular historical and social contexts. Second, the consensus is not necessarily - perhaps not even typically - very harmonous. With Vico (1744/2015, 56-57), for instance, we find an account of how the plebeians in the Ancient Rome had to struggle to have their proprietary rights protected against and recognised by the nobles. Illustrative enough is that the plebeians too in this struggle could appeal to an earlier emerged and accepted argument. What the human history and traditions can produce or find could thus be a multitude of premises, premises behind other premises, premises consistent or in tension or with each other, etc.

My remarks here already suggest that instead of, or in addition to, single facts or commands to do or not do something, a significant consensus would concern premises to which one can appeal while reflecting and arguing on some more particular matter. That consensus can be about premises as well, in turn, emphasises the possibly rational nature of the authority that they could have. There would be commonly recognised authority, yet also room for discussion and reasoning all the time, instead of simple obedience to straightforward authoritative claims. We thus could see an option of historically advancing evolvement of common rationality without any ontotheological foundations - or, at least, without too much of them.

Given our theme in this essay, finally, most noteworthy is the possible consensus and rationality related to moral issues in general and particularly, such issues within politics. Then again, emerging commonly recognised rationality could also be narrower and concern only the cognitive sphere and norms and criteria that one should mind while prusuing for knowledge. While discussing below the option to see in Naudé's thought some resemblance with the idea of constitutive history, we should consider the latter. I find it useful to make the distinction between seeing history plentifully constitutive of various rationalities in the human society and life, on one hand, and a narrower view of history constitutive of knowledge only. 


\section{Respublica literaria in and around the Naudéan library and knowledge-constitutive history?}

Damien $(1995,179)$ characterises the Naudéan library by the notion of "the republic of letters (la republique des lettres)" used by Naudé (1633, 97, and $1633 / 1641,105$, for instance) himself too, to depict the intercourse between the erudites. In Naudé's time, the expression had already become frequently used (Bots \& Waquet 1997, $11 \mathrm{ff}$; in continuation I shall use the latin expression respublica literaria $)^{14}$. Towards the eighteenth century, one formally and in writing stated as the attributes of respublica literaria ideals like equality, tolerating different confessions, freedom, and intellectual community or the common pursuit of the truth (op. cit. 23-27). We perhaps should remind that in some other respects too, advancing communication between the erudites was a theme in the seventeenth-century scholarship, which saw the emergence of scholarly journals, for instance. One of the early examples was even titled Nouvelles de la république des lettres (Nouvelles 1684).

The side of Naudé's library thought in which we most plausibly could find something reminiscent of egalitarian ideals is his ideal of a publicly open library. Naudé $(1627,114)$ seems to suggest as a pretty practical matter that if some wealthy enough person makes the effort of establishing and maintaining a library, it would be a good idea to make it publicly open. The library should be open even "for the least of men (au moindre des hommes)" who could benefit from it. Damien $(1995,262)$ concludes that Naudé created and reserved for the state the library model, a "matrix (matrice)", which only later could give "all the people the means of judging, let alone constructing the reason directing the actions of the state". Naudé, on the other hand, propably had neither any trust nor interest in such wide popular participation of the people in politics.

Despite Naudé's claim, furthermore, it would be plausible to assume that he could not even think that the least of all the men would visit his library. The Naudéan library was very much a library for in his time quite limited circles of erudites. "The least of men" could plausibly have been the least of erudites, such as some young student still in the early phase of his scholarly path, rather than in the most miserable conditions living hinterland blebs, or even some at least formally literate Parisian bourgeois or artisan. We above saw how Damien wrote about “egalitarian democracy of bibliography”, which,

14 According to Hans Bots and Françoise Waquet $(1997,11)$, the first known appearance of the expression respublica literaria is in a letter dated 6 July 1417 by a Venetian humanist to another in Florence. 
indeed, could testify of a kind of egalitarianism regarding the views and voices in the books. However, it could be too hasty to assume that the public openness of the Naudéan library could tell about any wider egalitarianism in his thought.

Interestingly related to the thematic of this essay, nevertheless, my realism-based reservations to Naudés solemn promise of an absolutely to everyone open library would divide the population into two parts. There would be those belonging to the tiny respublica literaria within and around the library. Then, there would be also the vast majority of the people. ${ }^{15}$ Furthermore, there would be a fundamental and most interesting difference between these parts of the people. Damien writes:

The institution of librarianship that Naudé pursues throughout his life would become to allow the constitution of a socio-normative milieu of truth, independently from the monopoly of the church [...] (Damien 1995, 111; my italics.)

To characterise the "socio-normative milieu of truth" and rationality characteristic of respublica literaria within and around Naudé's publicly open library, we perhaps could use Jürgen Habermas' notion of "communicative action". While addressing the vast majority of people, in turn, the dominant logic would be in the Habermasian concepts the logic of "strategic action”. (Habermas 1981/1984, 285 ff.). For Naudé, as we saw above, religion and morals were merely tools subordinated to the state and governing. Both religion and morals as such and innerly tend to claim themselves quite a high authority over humans and their actions. Appealing to something probably respected as an authority by those addressed can be quite an effective method of influencing the recipients - though not very sincerely appealing to the reason of those addressed. We thus could see here a strategic, success- and influencing-oriented logic. Within and around the Naudéan library, in turn, there indeed could have been a "public sphere" of the common use of reason in the Habermasian (1962/1991) sense, though at this phase, not properly bourgeois, let alone in the broader sense civic or popular (cf. Suominen 2019).

Reminding that history was all that was left for Naudé in his desperation, the library too, as the "socio-normative milieu of true" should rest on history

15 According to Bots and Waquet $(1997,101)$, the number of persons collected by the Academies in France in the seventeenth century would have been less than three hundred while the whole population of France in 1600 was around sixteen million (see Hoffman 1994, 226; McEvedy \& Jones, 1979, 57) 
in the form of the books having their origin, otherwise related to, or dealing with historical periods, events, developments, etc. There would be amounts of possibly each other challenging texts and views telling about or otherwise related to particular events - and there could be a true respublica literaria, a community pursuing truth within this purely historical flow of texts and views. After claiming that for Naudé "Knowledge is not without a past. [...] None really begins [to know], but continues laboriously" (see Introduction above), Damien continues:

Sometimes outdated or wrong, knowledge discover its history. A theory, by the way, does not arise from the real itself but polemic confrontation with other theories the knowledge about which consequently is decisive. (Damien 1995, 209)

The reasoning here could give us some - though highly speculative - foundation for thinking that in the small circle of erudites, Naudé too could have seen a kind of historical constitution of knowledge and shared understanding. Then again, history here could be constitutive only of in a technical sense applicable knowledge and foundations relevant to it.

\section{One historically constituted piece of genuine political morality even with Naudé?}

Finally, I would make a short remark on an instance where Naudé, after all, seems to bring into his political thought some real moral obligations and restrictions for those in power. Within the evolvement of the notion of prudentia discussed above, the specificity of Naudé's political thought, as depicted by Soll, would have been his interest in the wider spheres of politics and governing.

Not only does he [Naudé] create a purely utilitarian version of prudence, but he accentuates the civic aspect of prudence, expanding its range of applicability into the complex mechanics of the state (Soll 2014, 49).

It seems that Naudé at least should have recognised and agreed with a widely in history and in his time shared disapproval of tyranny defined by Aristotle as "monarchy ruling in the interest of the monarch" instead of governing "with regard to the profit of the community" (Aristotle-322BC/1959, 207) or "in the interests of those who are ruled" (as an alternative translation of the end of the definition by Mitchell 1988, 181). Naudé may now and 
then defend someone falsely blamed for tyranny because of violent methods of exercising power, for instance (Naudé 1639/1667, 6 ff.). Given the classical Aristotelian notion, however, we probably should consider violence as a consequence of the king's interest in his own good only, rather than tyranny's actual meaning. Naudé probably would or should not defend tyranny in the classical Aristotelian sense of the notion.

Since Classical Antiquity and through the Middle Ages (cf., for example, Gilson 1948, 454), tyranny had been an issue in political theory and reasoning. According to Jacques Bouveresse (2016, 79-80), “The state's notion becomes more precise at the end of the sixteenth and the beginning of the seventeenth century, simultaneously with the absolutist doctrine". Bouveresse mentions as "authors behind these both veins of thought" authors like "Bodin, Coquille, Loyseau, Cardin Le Bret, Richelieu”. According to these authors, furthermore:

The state is the sovereign: it is attached to the state, not the king; the king only acts in the name of the state, the sovereign authority. (Bouveresse 2016, 80.)

In Naudé's time, one used expressions like "public interest (l'intèrêt public)" (see, e.g., Richelieu -1642/1689, 244-245) or "common good (bien commun)" (see even Naudé 1639, 329, for instance). There thus could be a 'higher purpose' that the king, for instance, should serve. Naudé can accept even the most horrible actions, but it could be precisely for the state - not for the king's private benefit and interests.

The remarks here would imply that all the moral arguments were not absent, after all, from Naudés political thought. Neither, then, would they be absent from what the history and the library could and should teach, following the assumption made at the beginning of this essay. Then again, we probably could think that Naudé's way of raising the state above everything else is also the foundation of the 'engineerish', socio-technological, or even technocratic appearance that his political thought gives. Once justification of actions is reduced to a single particular instance, everything else becomes instrumental only.

\section{Concluding reasoning}

In Reasoning (1), we saw how Naudé's political views and his ideal of the uncensored and tolerant library had some remarkable consistency with the early phase of the early modern Tacitist historiography. To achieve accurate 
knowledge for the basis of one's actions, one should neither censor nor embellish anything - even if there otherwise could be some political reasons for such pursuits. Both the library and historiography, then, would appear as model books for successful operations. One would be looking for purely technical advice for successful actions. Moral ideals, obligations, or restrictions for those acting within politics would be absent from the understanding that such historiography and library would be promoting.

In Reasoning (2), we made quite a speculative excursion into other and different views of history in the early modern centuries. In Vico's philosophy of history and, in a sense, within Traditio Apostolica as well, history in itself would be the source of morality or, at least, of some interpretations of what is right and what is wrong. We have seen how history remained, according to Damien, the only foundation for Naudé after his desperation excluded ontotheological foundation.

Encouraged by formulations like "socio-normative milieu of true" by Damien, we could think that Naudé's suggestion of a publicly open library and respublica literaria within and around it contained some insight into constitutive history within the narrow literary circles around his library. However, we even then should consider what kind of knowledge Naudé wished the library to advance. Reasoning (1) strongly suggested that knowledge applicable in the technical sense would be the crucial kind of knowledge that the Naudéan library should provide to its readers, the community around it, and even the state and the society more extensively. This pursuit of the Naudéan library would be very well consistent with the early phase of the early modern Tacitist historiography. Already Critical Tacitism would have established and fortified some new moral foundations and ideals that one should have pursued within the political realm.

In this sense, as an allusion to the additional title "Birth of political reason in the seventeenth century France (Naissance d'une raison politique dans la France du XVIIe siècle)" of Damien's book, the political rationality born would seem very technocratic. I shortly remarked above that the 'engineerish' perspective with Naudé did not confine to politics. Mechanics was the ideal science for Naudé. Thus, we could consider Naudé as a very modern man, but modern in quite a restricted sense. He could well have been an exceptionally 
radical and thoroughbred representative of the early phase of what one sometimes denotes as the modern technical rationality. ${ }^{16}$

Closest to plentifully, also morality-constitutive history, we could come in my above assumption that Naudé would - or, at least, should - have disapproved tyranny. Condemning tyranny would have been an instance of genuinely moral restrictions for the one in power already. We perhaps could think that for Naudé, the obligation of the one in power to pursue the common good or public interests would be a part of the state's constitution. We still could think that the state - or even some state-like formations before we actually could talk about the state proper - was for Naudé as if a Vician historically constituted institution. In history, some genuinely moral obligations and restrictions for or virtues required from the sovereign or king as well would have emerged.

Given Naudé's otherwise seemingly quite 'engineerish' political views, on the other hand, we probably could make reservations to such an assumption.

I would assume that Naudé had in his mind nothing like Vico's philosophy of history where the various institutions have their origin. The state could have been for Naudé very much like a machine, and the ban of tyranny would simply be a kind of a technical advice or 'user instruction'. It would not be so good for the states themselves if those with supreme power pursued their own good only. Still, on the other hand, opposing exclusively the notion of the historically constituted, possibly by some functionality founded, moral obligations or restrictions and technical effectiveness of some tool-like structures is not unproblematic. Instrumentality and functionality are not so distant from each other.

Regarding common good as the aim that the actions of the one in power should advance and mentioned even by Naudé, a question might arise whether the good is common to all the people or perhaps only to the people that matter, so to speak? In the utterly unequal French early modern society, the latter could be a more realistic answer. We actually could think that the common good for Naudé could have been somehow common to the people whose social status was close to his own and those on whom the positions of Naudé and those like him were dependent. Thus, it would concern a relatively thin layer of people on the top of society or concretely dependent on them.

16 We could now consider, once again, Naudé's position as an assumed precursor of the modern library and information field. In some contributions emphasising the social and historical foundation of knowledge within LID-studies (cf. note xi), we perhaps could see somehow similar partialness of the socio-historical perspective and, ultimately, an untouched dominance of purely technical rationality. (Cf. Suominen 2016, 69 ff.) 
Had we reason to think that the common good advanced even by the Naudéan state would have been very extensively common, in any case, we actually could see in Naudé's view of politics still another kind of at least seemingly moral motive. We could see there a kind of most intermediately utilitarian philanthropy, a pursuit of bettering people's conditions of life by stabilising the social and political situation and avoiding inner conflicts and wars. Even the poorest and least of the people in an utterly unequal society could benefit from such policy. In view of this utilitarian philanthropy, actually, most unembellishedly realist understanding of the political reality and acting rather cynically according to it can advance most effectivelly especially the quantive objectives. Simultaneusly, however, recognising and respecting the rights of the individuals affected could become secondary - if present at all.

Finally, a short remark is in place on the role that Naudés view to history could have here. Naudé has no explicit and proper periodicalisation of history like the one we saw with Vico. Naudé was a practical man rather than a philosopher of history. Then again, we could assume that even Naudé saw in a particular way conceived of rationality as a determinant of his present or modern. The past, then, would have been quite different in this respect. There would have been no actual rationality in the modern sense - though some brave minds like Emperor Tiberius and Kind Louis XI could have been bold enough to think like a rational modern man.

Such a view of history divided into rational modern and quite a different past, in any case, could nullify something of the core of what I have denoted as the idea of constitutive history. The option of rational dialogue with the history, including what one in history has said about particular issues, would have vanished since there would be no more the foundation of sufficiently shared rationality. With this reservation, on the other hand, a rational dialogue could still be possible between the readers and books within the respublica literaria within and around the Naudéan library. One should only reduce into the limits of modern technical rationality what the books have to say. 


\section{References}

Abad, R. (2003). Une première Fronde au temps de Richelieu ? L'émeute parisienne des 3-4 février 1631 et ses suites. Dix-septième siècle, 2003/1 ( $\mathrm{n}^{\circ}$ 218), 39-70. https://doi. org/10.3917/dss.031.0039

Aristotle (-322BC/1959). Politics. Transl. by H. Rackham. William Heinemann. Aristotle assumingly died in $322 \mathrm{BC}$.

Armenteros, C. (2011). The French idea of history: Joseph de Maistre and his heirs 1794-1854. Cornell University Press.

Bakos, A. E. (1991). "Qui nescit dissimulare, nescit regnare": Louis XI and Raison d'etat During the Reign of Louis XIII. Journal of the History of Ideas, 52(3), 399-416. https:// doi.org/10.2307/2710044

Beam, E. M. (1982). The Use and Abuse of Machiavelli: The Sixteenth-Century French Adaptation. Journal of the History of Ideas, 43(1), 33-54. https://doi .org/10. 2307/2709159

Bodin, J. (1576). Six livres de la repvblique de I. Bodin Angeum. Iaques de Puys.

Bodin, J. (1576/1606). The six bookes of a commonweale. Out of the French and Latine Copies, done into Englifh, by Richard Knolles. Impensis Bishop. The first French publ. 1576.

Bots, H. \& Waquet, F. (1997). La république des lettres. Belin.

Boutier, J., \& Sintomer, Y. (2014). La République de Florence (12e-16e siécle). Revue française de science politique, 2014/6 Vol. 64, 1055-1081. https://doi.org/10.3917/rfsp.646.1055

Bouveresse, J. (2016). Le règne de Louis XIV, ou la rupture défnitive entre la société française et la monarchie. Les Annales de droit, 10, 77-96. https ://doi.org/10.4000/add. 332

Capurro, R. (1992) What is information science for. In P. Vakkari \& B. Cronin (eds.), Conceptions of library and information science (pp. 82-96). Graham Taylor.

Catteeuw, L. (2010). La paradoxe des mystères publiés: La raison d'État entre censure et publication (XVIe-XVIIe siècle). In A. Lefebre (ed.), Comparaisons, raisons, raisons d'État (pp. 178-205). Oldenbourg.

Cavaillé, J.-P. (1998). Gabriel Naudé: Destinations et usages du texte politique. Les Cahiers du Centre de Recherches Historiques. Archives, 20, Article 20. https://doi.org/10.4000/ ccrh.2539

Cavaillé, J.-P. (2011). Naudé, la prudence extraordinaire du coup d’État. Les Dossiers du Grihl. https://journals.openedition.org/dossiersgrihl/4807

Croce, B. (1911/1913). The philosophy of Giambattista Vico. Transl. by R.G. Collingwood. Howard Latimer. This volume represents the author's La Filosofia di Giambattista Vico (Bari, 1911) forming vol. ii. of his Saggi filosofici.

Damien, R. (1995). Bibliothèque et état. Naissance d'une raison politique dans la France du XVIIe siècle. Press Universitaire de France.

Du Tillet, J. (15??/1580). Reqveil des roys de France, levrs covronne et maison. Iaques du Puys. (Before printing, various maniscript versions during the 16th century.)

Du Tillet, J. (1545/1566). Recueil des rois de France. (A manuscript without a title page; beginning of the text: "Au tres chrestien roy de France, Charles, neufviesme du nom, mon souverain seigneur”. Dates of ed. 1545-1547, 1566.) 
Dunning, W. A. (1896). Jean Bodin on sovereignty: With some reference to the doctrine of Thomas Hobbes. Political Science Quarterly, 11(1), 82-104. https ://doi .org/10.2307/2139603

Gadamer, H.-G. (1960/1992). Truth and method (2nd rev. ed.). Crossroad. Publ. Orig. in the Germany 1960.Rev. English ed. based on 5th German ed. from 1986.

Gilson, É. (1947). Le thomisme: Introduction a la philosphie de saint Thomas d'Aquin. Cinquième édition revue et augmentée. Vrin.

Habermas, J. (1981/1984). The theory of communicaltive action. Volume 1, Reason and the rationalizalisation of society. Transl. by Thomas McCarthy. Beacon Press.

Habermas, J. (1962/1991). The Structural Transformation of the Public Sphere: An Inquiry into a Category of Bourgeois Society. MIT Press. Orig. German publ. 1962.

Hankins, J. (2016). Leonardo Bruni on the Legitimacy of Constitutions (Oratio in funere Johannis Strozze 19- 23. In C. T. Callisen (ed.), Reading and Writing History from Bruni to Windschuttle: Essays in Honour of Gary Ianziti (pp. 73-86). Routledge.

Hardman, J. (1999). Robespierre. Pearson Education.

Hoffman, P. T. (1994). Early Modern France 1450-1700. In Fiscal crises, liberty, and representative government 1450-170o: Making the modern freedom (pp. 226-252). Stanford University Press.

Hörcher, F. (2016). The Renaissance of Political Realism in Early Modern Europe: Giovanni Botero and the Discourse of "Reason of State". Krakowskie Studia z Historii Państwa i Prawa, 9(2), 187-210. https://doi.org/10.4467/20844131Ks.16.009.5329

Hörcher, F. (2019). The Lion and the Fox: Montaigne, Lipsius and Post-Machiavellian. Teoria Polityki, (3), 161-173. https://doi.org/10.4467/25440845tp.19.008.10291

Ježić, Lj. F. (2015). Viewing Vico within German Idealism On Jacobi’s Comparison of Vico with Kant and with Schelling's System of Identity. Synthesis Philosophica, 6o(2), 243-250.

Johnson, N. D., \& Koyama, M. (2012). Legal Centralization and the Birth of the Secular State. MPRA_paper_40887. (https://mpra.ub.uni-muenchen.de/40887/1/MPRA_paper_40887.pdf. Referred to 17 March 2020).

King, P. (1974). The ideology of order: A comparative study of Jean Bodin and Thomas Hobbes. Barnes \& Noble.

La Boétie, É. de (1549/1576/2009). Le discours de la servitude volontaire ou le contrun. Manuscrit de Mesme. (http://classiques.uqac.ca/classiques/la_boetie_etienne_de/discours_de_la_servitude/discours_servitude_volontaire.pdf. Referred to 16 Marsh 2021). Manuscript from 1549 first published in printing 1576.)

Lemke, A. B. (1991). Gabriel Naude and the Ideal Library. Syracuse University Library Associates Courier, XXVI(1), 27-44.

Lipsius, J. (1589/1632). I. Lipsi politicorvm sive civilis doctrinae libri sex: Qui ad principatum maxime spectant. Gvilielmvm Blaev. Orig. Publ. 1589.

Mali, J. (1989). Science, Tradition, and the Science of Tradition. Science in Context, 3(1), 143-173.

McEvedy, C., \& Jones, R. (1979). Atlas of world population history. Penguin Books.

Merriam C. E. Jr. (1900/2003). History of the Theory of Sovereignty since Rousseau. Batoche Books.

Miner, R. C. (1998). "Verum-factum" and Practical Wisdom in the Early Writings of Giambattista Vico. Journal of the History of Ideas, 59(1), 53-73. 
Mirabeau, H.-G. De (1775). Essai sur le despotisme. Londres.

Mitchell, L. (1988). Tyrannical oligarchs at Athens. In S. Lewis (ed.) Ancient Tyranny (pp. 178187). Edinburgh University Press.

Naudé, G. (1625). Apologie pour tovs les grands personnages qui ont este faussemcnt soupçonnez de magie. François Targa,

Naudé, G. (1627). Advis pour dresser vne bibliothèqve. François Targa.

Naudé, G. (1639/1667). Con-siderations politiques sur les coups d'estat. Sur la copie de Rome. S.l.: s.n., 1667. Orig. Publ. 1639.

Naudé, G. (-1653/1739). Reflexions historiques et politiques sur les mouens dont les plus grands princes \& habiles Ministres se sont servis pour gouverner et augmenter leurs etats. Herman Verbeek. Publ. posthumously only; Naudé died 1653.

Naudé, G. (1633). Bibliographia politica. Franscum Baba

Naudé, G. (1633/1641). La bibliographie politiqve dv Sr Navde. Guillaume Pele.

Nouvelles (1684/1966). Nouvelles de la république des lettres. Tome I. Comprénant les années 1684-1685. Slatkine Reprints. Issue Mois de Mars 1684, tome premiere, orig. publ. 1684 in Amsterdam by Henry Desbordes.

Qvortrup, L. (2007) The public library: from information access to knowledge management: a theory of knowledge and knowledge categories. Information Research, 12(4). (Proceedings of the Sixth International Conference on Conceptions of Library and Information Science-"Featuring the Future") (http://informationr.net/ir/12-4/colis/colis17.html Referred to 12 March, 2021)

Richelieu, A. du Plessis de (-1642/1689). Testament politique d'Armand du Plessis, cardinal duc de Richelieu. Henry Desbordes. Published in print only posthumously; Richelieu died 1642.

Sarpi, P. (1619/1974). Istoria del Concilio Tridentino. Einaudi. First published 1619 in London by the pseudonym Pietro Soave Polano.

Shera, J. (1970). Introduction to library science: Basic elements of library service. Libraries Unlimited.

Simon, R. (1690). Histoire critique des versions du Nouveau Testament. Reinier Leers.

Sievänen-Allen, R. (1978). Johdatus kirjastotieteeseen ja informatiikkaan. Otava.

Soll, J. (2003). Empirical History and the Transformation of Political Criticism in France from Bodin to Bayle. Journal of the History of Ideas, 64(2), 297-316. https://doi.org/10.1353/ jhi.2003.0030

Soll, J. (2014). The reception of the Prince 1513-1700, or why we understand Machiavelli the way we do. Social Research, 81(1), 31-6o.

Suominen, V. (2016). About and on behalf of scriptum est: The literary, bibliographic, and educational rationality sui generis of the library and librarianship on the top of what literature has produced. University of Oulu. http://urn.fi/urn:isbn: 9789526212302

Suominen, V. (2019). Gabriel Naudé - a librarian and a libertin between the Huguenot Wars and the Enlightenment. Informaatiotutkimus, 38(1), 23-48. https://doi.org/10.23978/ inf.79889

Szuromi, S. A. (2015). From Morality to Positive Law: Considerations from Theology, Legal Theory, and the History of Canon Law. Angelicum, 92(2), 195-212. 
Talja, S., Tuominen, K., \& Savolainen, R. (2004). "Isms" in information science: constructivism, collectivism and constructionism. Journal of Documentation, 61(1), 79-101. https://doi. org/10.1108/00220410510578023

Tavard, G. H. (1962). Tradition in early post-tridentine theology. Theological Studies, 23(3), 377405 .

Vico, G. ( 1710/1835). De antiquissima itaorum sapientia ex linguae latinae originibus eruenda: libri tres. In J.B. Vici opera latina (pp. 51-146). Tomus I. S.l., Mediolani. Orig. Publ. 1710.

Vico, G. (1744/1948). The New Science of Giambattista Vico. Transl. from the third ed. (1744) by Thomas Goddard Bergin and Max Harold Fisch. Cornell University Press.

Vico, G. (1744/2015). La Scienza nuova 1744. S.l., Instituto per la Storia del Pensiero Filosofico e Scientifico. (http://www.ispf-lab.cnr.it/2015_101.pdf. Referred to Feb. 19, 2021)

Wootton, D. (1983). Paolo Sarpi: Between Renaissance and Enlightenment. Cambridge University Press. 